\title{
PENDAMPINGAN KAUM REMAJA DALAM MENGEMBANGKAN IDENTITAS DIRI DAN SPIRITUALITAS HIDUP
}

\author{
Thomas Tokan Pureklolon ${ }^{1}$ \\ Christina Purwanti ${ }^{2}$ \\ Hanna Suteja ${ }^{3}$ \\ Universitas Pelita Harapan \\ thomas.pureklolon@uph.edu ,christina.purwanti@uph.edu, hanna.suteja@uph.edu
}

\begin{abstract}
Abstrak
Usia remaja adalah usia emas dalam fase kehidupan manusia karena berada di antara masa anak-anak dan masa dewasa. Kaum remaja memerlukan pendampingan secara berkesinambungan untuk mengenali identitas, gaya hidup, dan pengembangan sipritualitas mereka. Pendampingan terhadap para remaja di GBI Victoria Park Tangerang ini dilakukan secara rutin oleh orang-orang yang berkompeten dan mempunyai kepedulian secara langsung terhadap para remaja, yang nota benenya adalah generasi penerus bangsa. Peduli terhadap para remaja berarti secara langsung peduli terhadap bangsa. Oleh karena itu, pendampingan para remaja yang dijalankan ini bertujuan memberikan pembinaan kepada para remaja untuk lebih mengenal jati diri mereka, spiritualitas mereka dan memiliki keberanian untuk menyampaikan pendapat dan mampu berpikir secara kritis atas problem kehidupan yang dihadapi setiap hari; baik di rumah bersama anggota keluarga, maupun di sekolah dan di lingkungan bersama teman-temannya. Metode pelaksanaan pendampingan adalah dengan melakukan kegiatan pembinaan melalui webinar, yang meliputi tiga bagian utama yaitu dengan topik : 'Remaja dan Karakternya', 'Spiritualitas Remaja', 'Belajar Bahasa Inggris Melalui Alkitab'. Dalam pelaksanaan untuk masing-masing bagiannya, selalu diawali dengan acara menjawab pertanyaan sebelum memulai pembinaan dan menjawab pertanyaan setelah pembinaan berlangsung. Hasil kegiatan pendampingan ini menunjukkan tiga hal utama yakni: Pertama, para remaja dapat megenali apa arti identitas mereka yang sedang tumbuh menjadi dewasa melalui tahap-tahap perkembangannya terutama ketika masa akil baliq sampai dewasa dan terus mengenali karakteristik mereka dengan segala perubahannya. Kedua, para remaja mampu menentukan spiritualitas hidup mereka sesuai tren, gaya, mode dan selera yang sedang dijalani dewasa ini. Ketiga, para remaja dapat menggunakan Alkitab yang berbahasa Inggris, bukan hanya menjadi sarana untuk mengenal Tuhan lewat firmanNya, tetapi juga dapat menjadi sarana pembelajaran bahasa asing.
\end{abstract}

Kata kunci: Pendampingan, remaja, identitas, spiritualitas, karakter.

\section{PENDAHULUAN}

GBI Victoria Park yang beralamat di Ruko Victoria Park, Jalan Imam Bonjol Blok A2 No. 12, Bojong Jaya, Karawaci, Tangerang ini memiliki anggota jemaat dewasa dan sudah berkeluarga sebanyak 120 orang. GBI Victoria Park ini memiliki 5 komisi pelayanan, yaitu Komisi Anak, Komisi Remaja, Komisi Dewasa 
Muda, Komisi Bapak, dan Komisi Ibu. Jumlah anggota remaja yang ada di GBI Victoria Park adalah 11 orang pada kisaran usia 13-17 tahun dengan karakteristik dan minat yang beragam. Fokus yang menjadi perhatian dari pimpinan jemaat gereja selama ini adalah menjadikan remaja sebagai generasi penerus gereja yang mengenal jati diri dan memiliki spriritualitas yang kuat supaya ketika dewasa mereka dapat menjadi pribadi yang kuat beriman.

Berdasarkan analisis situasi, ada beberapa hal yang menjadi masalah bagi jemaat di GBI Victoria Park Tangerang, yaitu: 1) minimnya kesadaran bahwa masalah remaja tetap menjadi masalah yang aktual untuk setiap zaman. Kehadiran kaum remaja dengan beragam karakter tetap merupakan suatu tantangan bagi jemaat gereja, termasuk di dalamnya para orang tua dan semua umat yang ada di gereja; 2) kurangnya kesadaran bahwa seorang remaja harus lebih mengenal dirinya dan konteks situasi saat ini serta memiliki keberanian untuk menyatakan pendapat dan menyampaikan pertanyaan mengenai segala sesuatu yang dialami selama ini; 3) kurangnya kesadaran bahwa remaja harus kuat dari segi spiritualitasnya supaya ketika dewasa mereka dapat menjadi pribadi yang kuat beriman kepada Yesus Kristus; dan 4) pembinaan remaja harus dilakukan secara rutin oleh orang-orang yang berkompeten dan peduli pada generasi penerus.

Keseluruhan problematika yang telah dipaparkan menjadi perhatian serius dari para pimpinan jemaat, majelis, dan orang-orang yang berkompeten dalam bidang tersebut karena kaum remaja adalah ujung tombak generasi penerus gereja khususnya dan negara pada umumnya. Seperti yang diungkapkan oleh Hyde (2008, h. 13-29) bahwa setiap orang dewasa di dalam rumah haruslah memperhatikan dan mendorong berbagai pengalaman anak/remaja, sehingga mereka dapat masuk dalam kehidupan spiritual. Oleh karena itu anak/remaja membutuhkan dukungan dan dorongan yang berarti dari para orang yang lebih dewasa dalam bentuk pemberian teladan atau contoh. Dengan demikian para orang dewasa perlu membangun relasi dengan anak remaja, supaya mereka berani terbuka menceritakan pengalaman spiritual mereka kepada orang tua. Menurut Nye (2014), spiritualitas anak adalah berbagai cara Tuhan bersama anak dan berbagai cara anak untuk hidup di dalam Tuhan. Jadi spiritualitas anak merupakan kapasitas alami yang tumbuh di dalam diri anak untuk menyadari bahwa ada pengalaman hidup yang kudus.

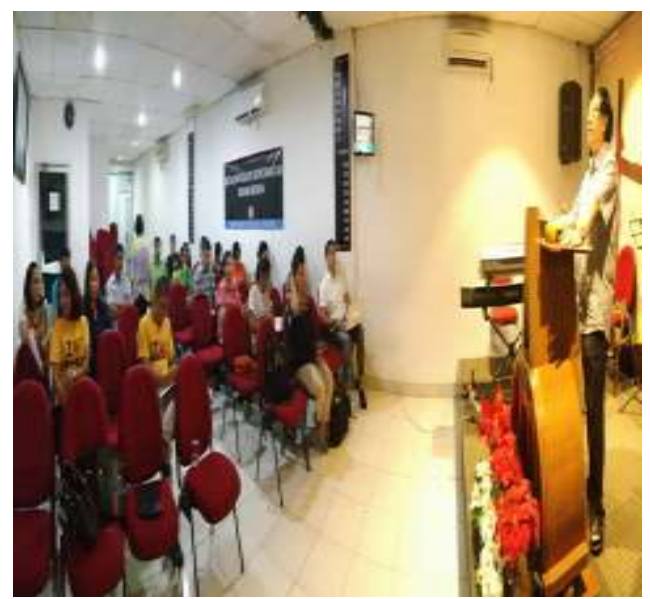

Gambar 1. Kegiatan pembekalan jemaat

Berdasarkan pendapat kedua pakar tersebut, maka solusi yang ditawarkan kepada pimpinan jemaat GBI Victoria Park adalah memberikan bimbingan kepada remaja melalui webinar yang berisi penjelasan siapa itu remaja dan bagaimana karakter remaja. Tujuan webinar ini adalah agar remaja di GBI Victoria Park dapat mengetahui jati diri, karakter, masalah yang dihadapi, dan cara mengatasinya. Riset yang dilakukan oleh Triwiyarto (2015) menunjukkan permasalahan remaja diawali karena kurangnya pengenalan remaja jati diri, karakter, dan masalah yang dihadapinya. Pendapat yang hampir sama dikatakan oleh Nugraha (2021) bahwa saat usia akil baliq adalah waktu seorang muda sedang menelusuri pencarian identitas diri. Orang tua dan orang dewasa di lingkungannya harus memberikan pendampingan agar remaja tidak salah arah.

Untuk membangun kesadaran bahwa remaja harus kuat dari segi spiritualitasnya supaya ketika dewasa mereka dapat menjadi pribadi 
yang kuat beriman kepada Yesus Kristus, maka pendampingan kepada remaja berikutnya adalah memberikan webinar tentang apa itu spiritualitas dan aplikasinya dalam kehidupan remaja. Konsep ini seperti yang diungkapkan oleh Tafonao (2018) bahwa pemuda adalah masa depan Gereja. Sebagai masa depan gereja, maka pemuda perlu mendapat pendampingan sejak dini untuk membangun iman yang kokoh dalam menghadapi dunia yang semakin maju dengan perkembangannya. Salah satu perkembangan dunia adalah teknologi. Selain itu pendampingan kepada kaum remaja juga dilakukan dengan membuat webinar dengan topik bagaimana belajar Bahasa Inggris melalui Alkitab untuk menarik minat remaja membaca Alkitab. Pendampingan keempat yang dilakukan adalah pendampingan untuk orang tua yaitu meningkatkan pemahaman orang tua akan pentingnya mengetahui perkembangan jati diri dan spiritualitas remaja sehingga ora tua dapat membimbing remaja dalam menghadapi permasalahan remaja.

Hasil dari pendampingan ini diharapkan remaja di GBI Victoria Park mengenal jati diri, karakter, dan memiliki spiritualitas yang kokoh sehingga remaja menjadi andalan dan masa depan Gereja dalam menghadapi dunia yang semakin maju dengan perkembangannya. Demikian juga orang tua memiliki pemahaman yang mendalam mengenai remaja dan karakternya sehingga mampu mendampingi dan membimbing remaja ke arah yang tepat.

\section{METODE}

Pendampingan ini memakai siklus pelatihan tradisional yang mencakup 4 komponen yang lazimnya terjadi dalam pendampingan yakni bagaimana melakukan penilaian, bagaimana membuat sebuah perencanaan, kemudian tekhnik penyampaian dan selanjutnya membuat sebuah evaluasi yang memadai dengan bersentral pada LEARN. Pemahaman tentang LEARN, berawal dari pemikiran yang dikemukakan oleh Furjanic and Trotman (2000, h. 2); dengan afirmasinya adalah sebuah prosedur natural yang dimiliki dan dilalui oleh pihak pembelajar sebelum menerima konsep dari pendampingan dan menggunakan konsep tersebut.

Akronim atau terminologi LEARN dapat disebut sebagai kompas atau pedoman arah dalam memaknai lima level yang semestinya dilalui oleh pihak pembelajar atau peserta pendampingan ketika memulai pada awalnya, berupaya untuk mempraktikkan, seterusnya berupaya untuk membuat pengaplikasian dan berupaya menginternalisasikan segala keterampilan atas konsep yang disampaikan. Selanjutnya secara jelas terminologi LEARN memiliki penjabarannya sebagai berikut: L merupakan afirmasi pada mendengarkan dan memahami (Listen and Understand). E dimaknai dengan mengevaluasi dan memutuskan (Evaluate and Decide). A bermakna berusaha dan membangun (Attempt and Build). R memiliki makna kembali dan mengaplikasikan (Return and Apply), dan selanjutnya $\mathrm{N}$ memiliki makna transisi alami (Natural Transition). Pada gambar 2 di bawah ini sangat jelas memperlihatkan secara transparan bagaimana sebuah pendampingan yang terus berjalan dalam proses.

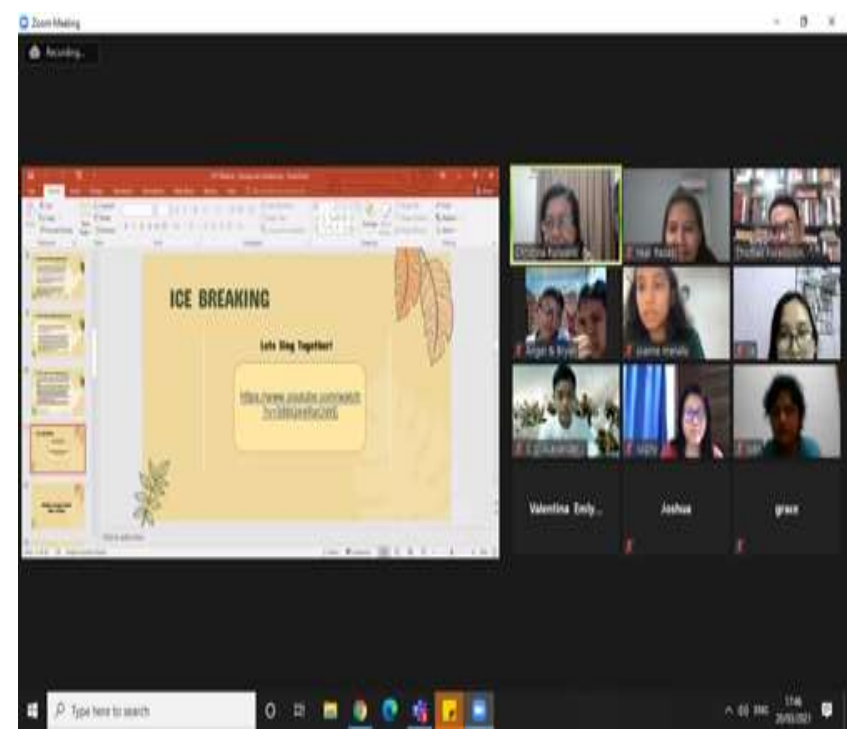

Gambar 2. Pendampingan dalam sebuah proses.

Langkah awal yang dijalankan oleh kelompok atau tim PKM yang menjadi tahap awal adalah penilaian. Problematika utama pada tahap ini adalah bagaimana mengklarifikasi PKM, mempelajari argumentasi utama tentang 
permohonan, dan bagaimana penentuan apakah substansi utama pelaksanaan pelatihan adalah respon yang tepat dan urgen yang harus dilakukan. (Furjanic and Trotman (2000, h. 7).

Setelah adanya penetapan bahwa pelaksanaan PKM merupakan pemecahan masalah, maka langkah berikut yang akan dilakukan adalah membuat perencanaan. Pada tahap ini, tim PkM memiliki sejumlah asumsi dasar dalam membuat perencanaan, seperti pengetahuan yang telah dimiliki oleh para remaja dengan problematikannya, pengetahuan yang dimiliki oleh orang tua dengan problematika dan kesenjangannya, bagaimana tujuan pendampingan, bagaimana mengidentifikasi dan merekrut mahasiswa tutor, bagaimana konten dan topik pendampingan, aktivitas seperti apa yang harus dilakukan, serta hal teknis lainnya yang juga sangat penting adalah soal penentuan jadwal kegiatan dan keseluruhan substansi materi lainnya (Furjanic \& Trotman, h. 23).

Tahap berikut yang merupakan tahap ketiga adalah tahap penyampaian konsep. Setiap pendamping dengan sendirinya harus memahami setiap problem kehidupan remaja yang berkaitan erat dengan memahami andragogi para peserta remaja dan orang tua yang selalu mengaitkan kebutuhan belajar dengan aktivitas pekerjaan, dan terutama tentang penyelesaian atas berbagai masalah. Setiap pendamping memiliki pertimbangan etis dari pola dan gaya hidup kaum remaja dan orang tuanya. Kegiatan pendampingan pun disertai dengan beragam materinya untuk masing-masing pertemuan yang bisa secara langsung menjawab beraneka kebutuhan (Furjanic \& Trotman, h. 62)

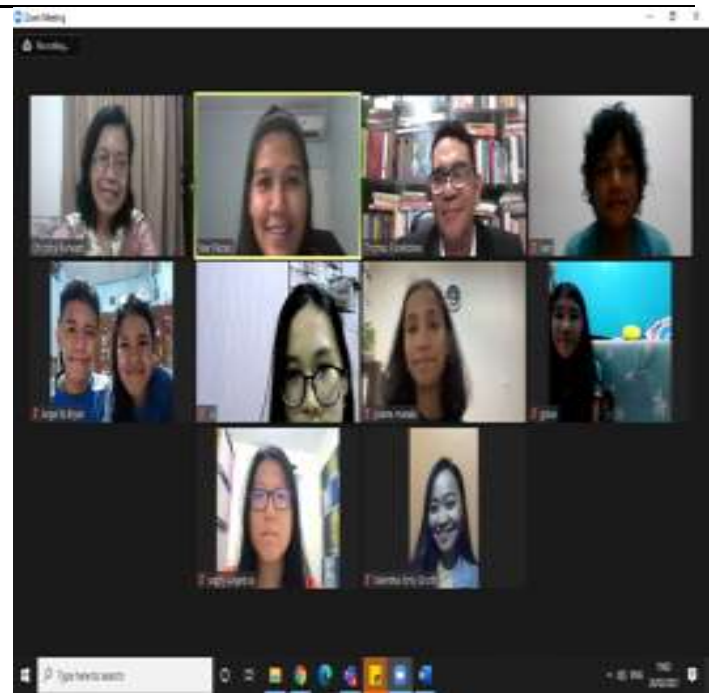

Gambar 3. Kegiatan Webinar

Tahap berikut yang merupakan tahap keempat adalah evaluasi pendampingan. Evaluasi yang terjadi secara perorangan sebetulnya secara langsung mau membantu pemimpin jemaat, pembimbing remaja, juga para pendamping dengan tujuan untuk menilai sejauh mana keefektifan pendampingan yang dijalankan selama aktivitas pendampingan berlangsung (Furjanic \& Trotman, h. 82). Pada setiap akhir pendampingan, setiap peserta diminta untuk melakukan evaluasi terhadap materi, proses, media, juga termasuk motivasi para peserta. Pada setiap pertemuan di bagian akhir, disediakan waktu khusus selama kurang lebih 10 menit untuk mengutarakan semacam internalisasi atau refleksi pendampingan tentang poin-poin atau ide-ide baru yang menginspirasi mereka dalam mengenal dan memahami jati diri, karakter, spiritualitas, dan menggunakan kemampuan Bahasa Inggris untuk belajar Alkitab. Di samping itu juga refleksi tentang berbagai hal menarik lainnya yang ditemukan tetapi belum sepenuhnya dipahami, dan yang ingin dketehui lebih lanjut. Dalam pemikiran Zendrato, tentang refleksi diri ini penting dilakukan secara terbuka, jujur dan transparan. Kaum remaja dan orang tua harus bisa melakukan transformasi diri dalam melakukan segala perbaikan dan perubahan. (Zendrato dkk., 2019, h. 130). Yang ditampilkan dalam refleksi ini berupa tanya jawab antara peserta remaja dan orang tua yang terjadi secara resiprokal timbal balik bergantian, agar pada setiap 
pertanyaan atau pun setiap permasalahan yang duhadapi ketika berlangsungnya pendampingan akan secepatnya ditangani.

Prinsip atau konsep LEARN diterapkan di seluruh aktivitas pendampingan yang mencakupi: Pertama, mendengarkan dan memahami. Setiap pendamping menciptakan sebuah ruang lingkup yang nyaman seperti mengenali setiap peserta, secara jelas menetapkan seluruh aturan main selama berlangsungnya pendampingan yang disertai dengan sebuah iklim yang kondusif dalam setiap aktivitas, serta yang paling utama adalah menyampaian tujuan pendampingan yang sedang berjalan (Furjanic \& Trotman, h. 101).

Kedua adalah membuat evaluasi dan memutuskan. Pada bagian ini, pendamping dapat menciptakan kondisi kegiatan yang memungkinkan para peserta untuk berpartisipasi dan terlibat secara aktif pada setiap proses pendampingan (Furjanic \& Trotman, h. 117).

Ketiga adalah berusaha dan membangun. Pada tahap ketiga ini, peran pendamping adalah menseleksi setiap aktivitas yang tentu membantu peserta untuk merefresh atau mengingat kembali segala konsep materi yang telah dipelajari, lalu secara pribadi mampu menginternalisasi nilai-nilai dan membangun keterampilan yang mereka butuhkan untuk mengelola memahami diri sendiri (Furjanic \& Trotman, h. 135).

Tahap keempat yang disebut: Kembali dan membuat aplikasi. Afirmasi pada tahap ini adalah pendamping mempersiapkan kegiatan tindak lanjut dan alat atau instrumen yang akan sangat membantu peserta dalam menerapkan hasil pendampingan untuk memahami jati diri dan karakternya (Furjanic $\&$ Trotman, h. 167).

Tahap kelima yang disebut transisi alami. Output pendampingan yang berhasil biasanya membuat pengindentifikasian dalam tingkah laku. Namun dalam tahap ini masalah tentang transisi tidak terlihat secara langsung dengan alasan utamanya adalah karena berkaitan langsung dengan perubahan perilaku yakni proses pengaktualisasian diri. (Furjanic \& Trotman, h. 191).

\section{KAJIAN HASIL DAN PEMBAHASAN}

\section{Pelaksanaan}

Pelaksanaan kegiatan PkM diawali dengan sebuah tahap yaitu identifikasi masalah dan menganalisis berbagai kebutuhan dengan aktivitas utamanya adalah melakukan pertemuan beberapa kali dengan pimpinan jemaat dan pembimbing remaja membahas kebutuhan remaja dan orang tua di GBI Victoria Park.

Setelah tercapai pada bagian ini, para pimpinan jemaat memutuskan untuk menyetujui program pendampingan ini. Empat dosen tim PkM mulai mengembangkan tujuan pendampingan, tim dosen lalu merekrut 2 mahasiswa tutor, mengembangkan topik pendampingan dan konten materi serta aktivitas pendampingan. Pada tabel $1 \mathrm{di}$ bawah ini terlihat jelas jadwal pendampingan yang terspesifikasi tentang tanggal pelaksanaan dan berisikan topik pada setiap pertemuan, pendamping yang memimpin, dan soal pengalokasian waktu.

Tabel 1. Pengalokasian Jadwal Pendampingan

\begin{tabular}{|c|c|c|c|}
\hline Tanggal & Materi & Pemateri & Waktu \\
\hline 20 Maret & Remaja dan & Christina & $17.00-$ \\
2021 & Karakternya & Purwanti & 19.00 \\
& & & WIB \\
\hline 10 April & Spiritualitas & Thomas & $17.00-$ \\
2021 & Remaja & Pureklolon & 19.00 \\
& & & WIB \\
\hline 17 April & Belajar & Hanna & $17.00-$ \\
2021 & Bahasa & Suteja & 19.00 \\
& Inggris & & WIB \\
& melalui & & \\
& Alkitab & & \\
\hline 8 Mei & Sikap dan & Hanna & $17.00-$ \\
& peran orang & Suteja, & 19.00 \\
& tua dalam & Christina & WIB \\
& menghadapi & Purwanti. & \\
& remaja & Thomas & \\
& & Pureklolon, & \\
& & dan Year & \\
& & R. & \\
\hline
\end{tabular}

Pada setiap pertemuan, Tim PkM selalu membuat rancangan aktivitas pendampingan yang 
beragam agar dapat merespon atau pun mengakomodasi berbagai ragam gaya belajar dari para peserta. Hal ini sangat berpengaruh langsung terhadap peningkatan motivasi belajar dari para peserta pendampingan. Pemahaman poin ini selalu didukung oleh konsep pemikiran dari Antelm dengan premis utamanya adalah aktivitas belajar akan selalu membantu para peserta pendampingan agar lebih fleksibel dan diharapkan bisa menentukan dan menetapkan cara belajar meraka sendiri (Antelm-Lanzat dkk., 2021, h.1). Pada bagian ini, Tim PkM selalu merancang komponenkomponen yang akan disharingkan saat refleksi terjadi.

Uraian secara detail, konsep pemikiran LEARN dapat teridentifikasi secara langsung dari beberapa aktivitas pendampingan. Terlihat secara jelas, konsep mendengarkan dan memahami, terlihat secara jelas dari penyampaian tujuan pendampingan ini pada aktivitas di kegiatan pertama. Pada Gambar 4 di bawah ini terlihat salah satu slide yang dipaparkan pada pertama yang berisikan tujuan pelatihan atau pendampingan

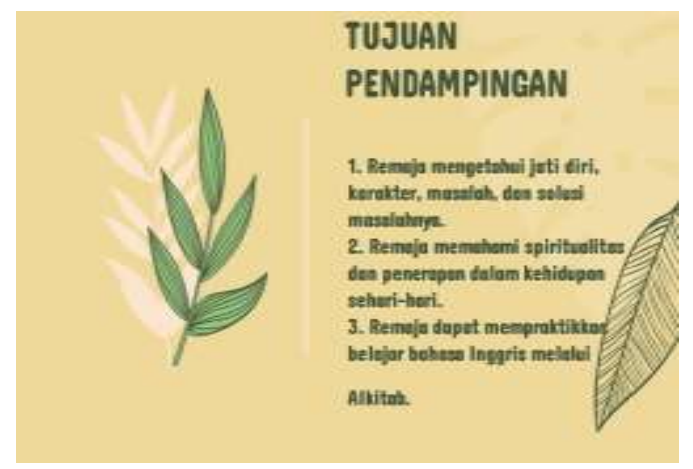

\section{Gambar 4. Slide Tujuan Pendampingan}

Setelah tujuan diketahui secara jelas dan terang benderang, peserta akan belajar secara efisien atas setiap aktivitas pendampingan dan para peserta pendampingan dalam hal ini bisa berfokus. Situasi pendampingan seperti ini sangat berguna bagi peserta karena secara langsung akan mengurangi kecemasan peserta dalam upaya mencapai kesuksesan dan sekaligus menumbuhkan motivasi secara internal pserta (Pitler \& Stone, 2012).
Pemabahasan pada konsep mengevaluasi dan memutuskan secara jelas, dapat terlihat pada salah satunya dari upaya menciptakan situasi pendampingan di mana peserta didik secara langsung terlibat dalam proses pendampingan. Mereka pun yakin bahwa partisipasi dan keterlibatan mereka secara aktif sebenarnya menjadi faktor kunci dalam proses pendampigan.

Pada gambar 5 memperlihatkan aktivitas webinar dan dialog secara daring di mana setiap peserta memiliki porsi yang sama dalam mensaharingkan atau mengekspresikan seluruh pendapat mereka secara rileks dan terbuka. Dalam gambar ini pun terlihat sebuah diskusi yang sedang berjalan secara konstruktif yang langsung dipandu oleh Tim PkM.

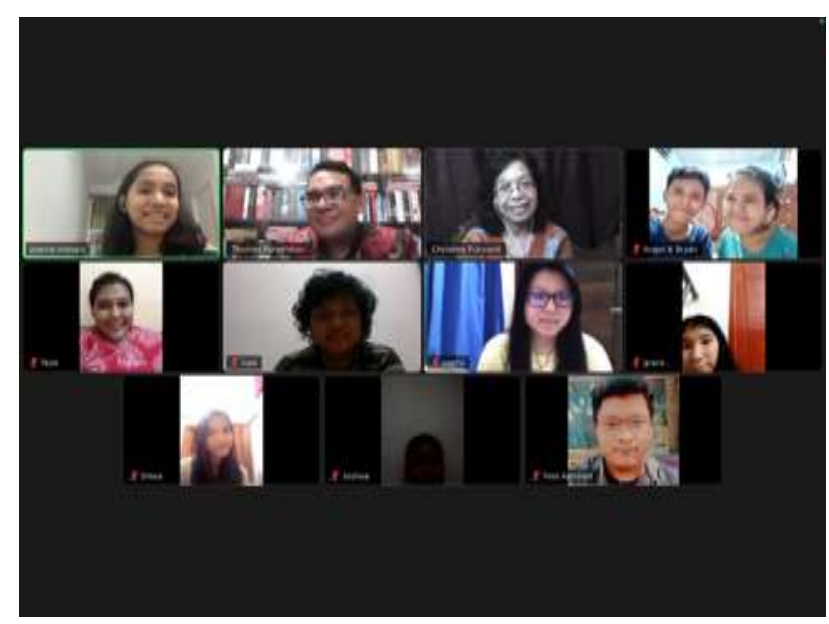

Gambar 5. Diskusi daring

Pada konsep berusaha dan membangun, pada bagian ini terlihat jelas pada tugas para pendamping untuk bisa menseleksi aktivitas yang berkaitan langsung dengan membantu peserta untuk mengingat konsep-konsep yang telah dipelajari, juga mengimplementasi nilai-nilai secara pribadi yang selalu peserta butuhkan untuk pengenalan jati diri, karakter, spiritualitas, dan praktik Bahasa Inggris mereka. Pada gambar 5 terlihat secara jelas aktivitas webinar di mana terlihat masing-masing peserta diminta untuk memikirkan mengapa mereka perlu belajar yang bisa dikerjakan pada awal di hari pertama sekolah. 


\section{Why learning English from the Bible?}

-We are Christians.

- We are familiar with the Bible.

- Bible is an authentic source.

- Bible has many versions (NIV, KJV, NKJV, etc)

- Bible has many useful app (audio/video)

\section{Gambar 6. Slide Webinar}

Pada konsep kembali dan mengaplikasikan dapat terlihat pada penyiapan aktivitas tindak lanjut bagi peserta. Bahwa para pendamping secara jelas menyiapkan aktivitas tindak lanjut yang akan membantu para peserta di dalam upaya menerapkan hasil webinar pengenalan jati diri, karakter, spiritualitas, dan belajar Bahasa Inggris melalui Alkitab. (Furjanic \& Trotman, h. 167). Salah satunya dengan tanya jawab dari tiap sesi.

Poin penting pada bagian terakhir adalah konsep transisi alami. Konsep kunci pada bagian ini adalah terlihat pada perubahan perilaku. Perubahan perilaku adalah pengidentifikasian yang terjadi secara efektif pada masa transisi, namun tetap terjadi di dalam proses dan membutuhkan waktu yang lama karena hal ini tentu sangat berkaitan langsung dengan perilaku paserta itu sendiri. Dengan demikian, para pimpinan jemaat dan pembimbing remaja seharusnya terus mengawasi atau memantau perkembangan setiap remaja di dalam seluruh aktivitas mereka ketika menjalan tugas mereka secara khusus pada saat melakukan tugas mengajar di kelas.

Pendampingan yang terjadi secara keseluruhan, dilaksanakan selama 4 pertemuan. Awal pertemuan pertama terjadi pada Sabtu (20 Maret 2021), pukul. 17.00-19.00 secara daring melalui aplikasi zoom. Pendampingan berbentuk webinar ini dihadiri oleh 3 dosen pendamping, 2 mahasiswa tutor, dan 12 remaja. Acara dimulai dengan ibadat Komsel yang dipimpin oleh salah satu remaja bernama Ivan, dengan doa pembukaan, nyanyian pembuka, webinar, tanya jawab, pengumuman, dan doa penutup. Pokok utama yang dibahas dalam topik pertama adalah pengertian remaja, karakteristik remaja, dan bagaimana remaja memahami perubahan dirinya, dibantu dengan orangtua, teman, dan lingkungan sekitar.Di akhir sesi ini ditutup dengan tanya jawab dan umpan balik.

Pertemuan kedua dilaksanakan pada Sabtu (10 April 2021), pukul 17.00-19.00 secara on line atau daring juga melalui aplikasi zoom. Kegiatan pendampingan ini dihadiri oleh 3 dosen pembimbing, 5 orang mahasiswa tutor, dan 12 remaja. Materi webinar pada saat itu dengan topik 'Spiritualitas Remaja: Sebuah Pilihan'. Acara dibuka dengan Komsel dipimpin oleh remaja Angel dengan doa pembukaan, nyanyian pembuka, webinar, tanya jawab, pengumuman, dan doa penutup. Pokok utama yang dibahas dalam topik kedua ini adalah sebagai berikut: Bahwa spiritualitas, memiliki kata dasar spirit yang berarti: jiwa, sukma dan roh yang dimiliki oleh setiap orang, yang dalam hal ini adalah setiap kaum remaja. Spirit yang diperolehnya dari orang tua dan lingkungan sekitarnya mejadi "sebuah kompas hukum" yang mengawalinya dalam pergaulannya, terlebih dalam menentukan identitasnya. Dengan mengenal identitasnya, kaum remaja bisa percaya diri dalam menjalankan seluruh tugas yang dipercayakan, oleh guru, oleh orang tua, atau pun oleh pendeta. Pemahaman tentang spiritualitas sebetulnya mampu menentukan makna, tujuan, dan moralitas kehidupan bagi kaum para remaja sendiri. Di akhir sesi diadakan Tanya jawab dan umpan balik.

Pertemuan 3 dilaksanakan pada hari Sabtu 17 April 2021 pukul 17.00-19.00 secara daring melalui aplikasi zoom. Acara Komsel dipimpin oleh remaja Grace diawali dengan doa pembukaan, nyanyian pembuka, webinar, tanya jawab, doa penutup. Dalam webinar ketiga tersebut, Ibu Hanna mengatakan bahwa saat ini belajar bahasa asing dapat dilakukan dengan menggunakan berbagai sumber yang dengan mudah dapat kita akses. Salah satu sumber yang sangat dekat dengan kita, umat kristiani, adalah Alkitab. Singkat kata Alkitab dapat menjadi sumber belajar bahasa 
Inggris yang sangat praktis dan relavan untuk kehidupan umat kristiani.

Pertemuan 4 dilaksanakan pada hari Sabtu, 8 Mei 2021 pukul 17.00-19.00 dihadiri 4 dosen, 2 mahasiswa tutor, remaja dan orang tua. Acara dimoderatori oleh Ibu Year dengan susunan acara doa pembukaan, perkenalan nara sumber, pemaparan materi secara singkat tiap nara sumber, tanya jawab, dan doa penutup. Webinar keempat ini diisi dengan pemaparan sikap dan peran orangtua dalam menghadapi remaja zaman sekarang. Ada beberapa hal yang dibahas yaitu orangtua harus memahami dan mengerti perkembangan remajanya, mempunyai rasa senang bergaul dengan putraputrinya, aktif mengikuti perkembangan remaja, dan selalu menyempatkan diri untuk dialog dengan putra-putrinya. Acara diakhiri dengan tanya jawab seputar masalah orangtua dalam menghadapi remajanya. Kemudian ditutup dengan doa penutup.

\section{Hasil Kegiatan}

Berdasarkan hasil evaluasi bersama tim GBI Victoria Park dan hasil evaluasi pre test dan post test yang diberikan kepada peserta setiap awal sesi kegiatan maupun di akhir sesi kegiatan, Tim PKM menganalisis adanya situasi sebagai berikut: 1). Para remaja dapat mengetahui lebih dalam tentang dunia remaja, seperti karakteristik dalam setiap tahapan remaja, perubahan yang akan dialami oleh remaja, serta pengaruh dalam kehidupan sehari-hari. Para remaja juga semakin menyadari betapa pentingnya makna, nilai dan tujuan dalam setiap peristiwa hidupnya. Remaja menjadi semakin bahagia (rileks) dan semakin efektif dalam menjalani kehidupannya. 2).Remaja semakin menyadari adanya relasi secara intens; dalam artian lebih dekat mengalami pengalaman bersama Tuhan dalam relasinya dengan orang lain, dan bisa peka terhadap seluruh pengalaman hidup bersama orang lain baik dalam kalangan remaja sendiri atau pun bersama dengan orang yang sedikit berbeda usia dalam satu rumah, dalam kelompok belajar atau dalam pertemuan ibadah. Remaja mulai mendengarkan nasihat orang tua, para guru dan bisa mengambil hikmah dan langkah penting dalam pergaulan dengan sesamanya. Dari sinilah terlihat spiritualitas kaum remaja menjadi lebih baik karena berasal dari keluarga Kristen keseluruhan pola hidupnya adalah takut akan Tuhan. Kaum remaja terlihat peka terhadap lingkungan dan mulai menghargai orang lain atau sesamanya serta mulai melihat betapa pentingnya lingkungan sekitar yang bisa membetuk spiritualiatas hidupnya. 3). Para remaja menyadari adanya sumber belajar bahasa asing yang sebenarnya dekat dengan kehidupan umat kristiani dan belajar bagaimana memanfaatkannya untuk pembelajaran bahasa Inggris. Sesudah webinar, pembina grup menyebutkan para peserta mulai mengunduh aplikasi Bible di ponsel mereka. Mereka juga mengusulkan agar sesekali mereka menggunakan bahasa Inggris ketika terjadi forum pembinaan rutin mereka. Dengan demikian, secara langsung mereka dapat mengaplikasikan segala hal yang telah mereka pelajari selama kegiatan tentang Bible. Berdasarkan informasi tersebut dapat disimpulkan bahwa para remaja memberikan tanggapan positif akan topik webinar ini dan langsung ingin mempraktikkannya. 4). Para orang tua pun mendapatkan motivasi dan semangat untuk tetap dapat mengarahkan anak remaja menjadi anak yang takut akan Tuhan.

\section{KESIMPULAN}

Kegiatan PkM ini adalah pengalaman yang mengesankan baik bagi kami tim dosen dan mahasiswa juga mitra $\mathrm{PkM}$ karena pelaksanaan PkM dilangsungkan secara daring. Dari mulai rapat persiapan, pelaksanaan, sampai penutupan semua kegiatan menggunakan aplikasi zoom meeting. Meskipun secara daring, kualittas dan kebermaknaan kegiatannya tetap terjaga. Sama halnya dengan tim dosen dan mahasiswa, para remaja dan orangtua di GBI Victoria Park Tangerang pun baru kali ini melakukan kegiatan PkM yang di dalamnya ada webinar secara daring. Melalui kerjasama yang baik dan komunikasi yang intensif, acara dapat berjalan secara lancar sebanyak 4 kali pertemuan.

Pandemi Covid-19 pada satu adaptasi kebiasaan belajar yang baru. Sungguh sebuah pengalaman yang berharga bagi remaja dan orang tua jemaat gereja GBI Victoria Park Tangerang, sebuah gereja yang sederhana di Victoria Park 
Tangerang yang memiliki banyak keterbatasan untuk melibatkan teknologi dalam kegiatan PkM ini.

Sesuai dengan kuesioner dan respon test yang diberikan kepada peserta pendampingan baik remaja maupun orang tua yang merasakan manfaat program ini maka tim dosen berencana menyelenggarakan hal yang serupa dengan topik yang berbeda untuk jemaat dewasa dan orangtua. PkM berikutnya akan difokuskan untuk level jemaat dewasa dan orang tua. Format dan jenis kegiatan akan ditentukan dalam proposal selanjutnya.

\section{UCAPAN TERIMA KASIH}

Ucapan terima kasih pertama disampaikan kepada Universitas Pelita Harapan (UPH). UPH telah menyetujui dan mendukung aktivitas Tri Dharma Perguruan Tinggi khususnya Kegiatan Pengabdian kepada Masyarakat, dengan topik: Pendampingan Remaja dan Orang Tua dalam Mengembangkan Jati Diri dan Spiritualitas di GBI Victoria Park Tangerang dengan nomor PkM: No. PM-008-M/FIP/II/2021. Ucapan terima kasih juga ditujukan kepada Pendeta Ir.Suyapto Tandyawasesa,M.Th. selaku pimpinan jemaat GBI Victoria Park Tangerang yang telah mendukung dan menyetujui terselenggaranya kegiatan Pengabdian kepada Masyarakat ini.

\section{REFERENSI}

Antelm-Lanzat, A. M., Gil, A. J., CacheiroGonzález, M. L., Pérez-Navío, E., \& Fonseca-Pedrero, E. (2020). Learning Styles and Vocational Guidance in Secondary Education. Educational Sciences: Theory and Practice, 20(3), 1Furjanic,S.W., \& Trotman,L.A. (2000). Turning

Training into Learning: How to Design and Deliver Programs That Get Results. AMACOM Div American Mgmt Assn.

Hyde,B. (2008). Children and Spirituality:Searching for Meaning and Connectedness.Jessica Kingsley Publisher.

Nugraha, Jevi. (2021). Masalah Remaja dan
Cara Mengatasinya. Jakarta: Merdeka

Nye,R. (2014). Children's Spirituality: What is this and Why it Matters. Canterbury Press.

Pitler, H., \& Stone, B. (2012). A Handbook for Classroom Instruction that Works. USA: ASCD.

Tafonao, Talizaro.(2018). "Peran Gembala Sidang dalam Mengajar dan Memotivasi untuk Melayani Terhadap Pertumbuhan Rohani Pemuda." Evangelikal: Jurnal Teologi Injili dan Pembinaan Warga Jemaat, Vol. 2.

Triwiyarto,Uut. (2015). Penyebab Kenakalan Remaja:Studi Kasus. Skripsi Fakultas Psikologi Universitas Sanata Dharma Yogyakarta.

Zendrato, J dkk. (2019). Kurikulum bagi pemula: Tinjauan teori dan aplikasi dalam perspektif kristiani. Jawa Tengah: CV Oase Group. 